\title{
UPAYA MENINGKATKAN KEAKTIFAN BELAJAR PESERTA DIDIK KELAS VIIA DENGAN MODEL PROBLEM BASED LEARNING DI MTS MUHAMMADIYAH TRUCUK KLATEN TAHUN PELAJARAN 2021/2022
}

\author{
Sriwiyata \\ Universitas Widya Dharma Klaten, Indonesia \\ sriwiyata107@gmail.com
}

\begin{abstract}
ABSTRAK
Permasalahan yang melatarbelakangi dari penelitian ini adalah bagaimana upaya meningkatkan keaktifan belajar peserta didik kelas VII A dengan model Rroblem Based Learning (PBL) di MTS Muhammadiyah Trucuk Klaten Tahun Pelajaran 2021/2022. Metode dalam penelitian ini menggunakan penelitian tindakan kelas (classroom action research). Penelitian tindakan kelas ini dilaksanakan di MTS Muhammadiyah Trucuk Klaten. Adapun waktu penelitian ini direncanakan selama 6 bulan. Waktu penelitian dimulai dari Maret hingga Oktober 2021 Sebagai subjek dalam penelitian ini adalah siswa kelas VIA yang berjumlah 30 orang. Adapun Langkah - langkah dari penelitian tindakan : perencanaan, pelaksanaan, pengumpulan data dan refleksi pada masing - masing langkah menggunakan dua siklus. Hasil penelitian pada pra siklus dapat menunjukkan tingkat keaktifan peserta didik rata rata $62 \%$. Sedangkan pada siklus I rata-rata keaktifan peserta didik dari indikator 1 sampai dengan 12 mencapai $74 \%$ Pada siklus II keaktifan peserta didik dengan rata-rata $73 \%$. Dengan demikian disimpulkan bahwa adanya peningkatan terhadap keaktifan peserta didik dalam pembelajaran pada materi perumusan dan pengesahan UUD NRI 1945 di MTS Muhammadiyah Trucuk Klaten.
\end{abstract}

Kata Kunci: keaktifan, pbl, UUD NRI 1945

\section{IMPROVING STUDENTS' LEARNING ACTIVENESS AT GRADE VIIA THROUGH PROBLEM BASED LEARNING MODEL OF MTS MUHAMMADIYAH TRUCUK KLATEN IN THE ACADEMIC YEAR 2021/2022}

\begin{abstract}
The purpose of this research was to increase students' learning at grade VII A through Problem Based Learning (PBL) at MTS Muhammadiyah Trucuk Klaten in the academic year 2021/2022. The method in this study was classroom action research. This classroom action research was conducted at MTS Muhammadiyah Trucuk Klaten. This research was conducted for 6 months starting from March to October 2021. The subjects in this study were 30 students at grade VIA. The steps of action research included planning, implementation, data collection, and reflection on each step for two cycles. The results of the pre-cycle research showed that the average level of students' activness was $62 \%$. Meanwhile, in the first cycle, the average activeness of students from indicators 1 to 12 reached 74\%. In the second cycle, the activeness of students was an average of $73 \%$. Thus, it was concluded that there was an increase in the activeness of students in learning on the material for the formulation and ratification of the 1945 Constitution of the Republic of Indonesia at MTS Muhammadiyah Trucuk Klaten.
\end{abstract}

Keywords: activitie, pbl, 1945 constitution of the republic of indonesia

\begin{tabular}{|c|c|c|}
\hline Submitted & Accepted & Published \\
\hline 30 September 2021 & 15 November 2021 & 27 November 2021 \\
\hline
\end{tabular}

\begin{tabular}{|l|c|c|}
\hline Citation & $:$ & $\begin{array}{c}\text { Sriwiyata, S. (2021). Upaya Meningkatkan Keaktifan Belajar Peserta Didik Kelas VIIA Dengan Model Problem Based } \\
\text { Learning Di Mts Muhammadiyah Trucuk Klaten Tahun Pelajaran 2021/2022. Jurnal PAJAR (Pendidikan dan } \\
\text { Pengajaran), 5(6), 1799-1806. DOI : http://dx.doi.org/10.33578/pjr.v5i6.8569. }\end{array}$ \\
\hline
\end{tabular}

\section{PENDAHULUAN}

Pada saat ini penggunaan metode ceramah lebih mendominasi selama proses pembelajaran, sehingga guru dalam pendekatan pembelajaran berorientasi terpusat pada dirinya sendiri. Metode ceramah adalah metode yang boleh dikatakan sebagai metode tradisional, karena sejak dahulu metode ini sudah dipergunakan sebagai alat komunikasi lisan antara guru dan anak didik dalam interaksi edukatif.

Kelemahan metode ceramah adalah: 1) kegiatan pembelajaran menjadi verbalisme (pengertian kata-kata), 2) anak didik yang lebih tanggap dari sisi visual akan menjadi rugi dan anak didik yang lebih tanggap auditifnya akan lebih 
cepat menerimanya, 3) bila terlalu lama akan membosankan, 4) sukar mengontrol sejauh mana perolehan belajar anak didik dan, 5) menyebabkan anak didik pasif (Jamal Ma'mur Asmani : 2012)

Kondisi ini juga terjadi di MTS Muhamadiyah Trucuk khususnya pada kelas VII A, berdasarkan hasil pengamatan terhadap pembelajaran PPKn pada materi "Perumusan dan Pengesahan UUD NRI 1945" di kelas tersebut, dalam proses pembelajaran guru sering menggunakan metode ceramah sehingga peserta didik kurang aktif dalam pembelajaran. Hal ini ditunjukkan dari 30 peserta didik yang sering bertanya ataupun mengemukakan pendapat pada waktu proses pembelajaran berlangsung hanya 4 orang $(12.50 \%)$. Hal tersebut menyebabkan hasil belajar peserta didik rendah, masih terdapat peserta didik yang belum mencapai nilai KKM < 75. Dari hasil evaluasi setelah pembelajaran selesai hanya 6 orang $(18.75 \%)$ yang hasil belajarnya sudah mencapai KKM $>75$, sedangkan 26 orang $(81.25 \%)$ masih mendapatkan nilai dibawah KKM $<75$.

Dalam merancang sebuah pembelajaran tidak lepas dari indikator dan tujuan pembelajaran yang akan dicapai. Untuk mencapai hal itu dalam sebuah pembelajaran kita membutuhkan cara atau metode pembelajaran yang tepat. Pada umumnya guru hanya menggunakan metode ceramah/konvensional, hal ini dikarenakan PPKn hanya berbentuk bacaan teoretis yang dihafal, guru kurang kreatifnya dalam menyajikan pembelajaran. Untuk mengatasi Peserta Didik yang kurang aktif dalam proses pembelajaran berdampak pada hasil belajar yang rendah maka di lakukan penelitian tindakan kelas (PTK) dengan menerapkan model pembelajaran $P B L$

Berangkat dari latar belakang tersebut, perlu ditemukan cara yang baik untuk menyampaikan konsep yang diajarkan di dalam mata pelajaran tertentu, sehingga peserta didik dapat menggunakan dan mengingat lebih lama konsep-konsep tersebut sebagai suatu kompetensi yang berguna. Di samping itu, guru dituntut kemampuannya untuk berkomunikasi secara efektif dengan peserta didiknya. Konsekuensi logis dari tuntutan profesionalitas ini adalah kemampuan menemukan pendekatan dan strategi pembelajaran yang tepat sesuai dengan kekhasan mata pelajaran tertentu.

Pendekatan pembelajaran berbasis masalah (Problem-Based Learning) adalah suatu pendekatan pembelajaran yang menggunakan masalah dunia nyata sebagai konteks bagi peserta didik untuk belajar tentang cara berfikir kritis dan keterampilan memecahkan masalah. Dengan asumsi dasar pada batasan masalah tersebut, $\mathrm{P} B L$ menjadi relevan untuk diterapkan sebagai strategi pembelajaran PPKn. Dengan pendekatan $P B L$ diasumsikan belajar PPKn akan menarik karena objek yang dipelajari situasi dunia nyata yang dekat dengan kehidupan peserta didik. Di samping itu, konsep pengetahuan esensial yang dipelajari akan menggerakkan pada kemampuan berpikir tingkat tinggi, dan dengan sendirinya akan mendorong peserta didik untuk belajar pada situasi bagaimana belajar.

Untuk mengatasi masalah di atas diperlukan model yang tepat dalam proses pembelajaran agar siswa dapat berpikir kritis, kreatif, logis, serta bersikap ilmiah. Model yang akan digunakan dalam mengatasi permasalahan ini adalah $P B L$, dengan model PBL siswa selalu diajak berpikir untuk menghadapi masalah dunia nyata yang berhubungan erat dengan materi yang dipelajari.

Dari permasalahan di atas, menjelaskan bahwa model $P B L$ adalah salah satu model pembelajaran yang baik untuk meningkatkan hasil belajar pada kemampuan pemecahan masalah. Hal ini sejalan dengan hasil penelitian Hendriana dkk (2018) menyatakan bahwa model PBL lebih baik dibandingkan dengan pembelajaran konvensional ditinjau dari kemampuan pemecahan masalah matematika.. Sedangkan menurut Widyatiningtyas dkk (2015) berpendapat bahwa model $P B L$ adalah sebuah pendekatan pembelajaran yang menantang bagi siswa untuk belajar pemecahan masalah yang dilakukan secara kelompok. 


\section{KAJIAN TEORETIS}

\section{Keaktifan}

Zaini (2011) keaktifan belajar juga dapat dikatakan aktivitas belajar, dan keaktifan belajar dapat dilihat dari aktivitas fisik dan mental siswa selama proses pembelajaran. Jika siswa sudah terlibat secara fisik dan mental, maka siswa akan merasakan suasana belajar yang lebih menyenangkan sehingga hasil belajar dapat diaktifkan. Belajar aktif merupakan suatu kegiatan yang dilakukan dengan rajin dan sungguhsungguh. Kegiatan di sini sering diartikan dengan kesibukan dan kegiatan yang mengarahkan seluruh tenaga, pikiran atau badan untuk mencapai suatu tujuan. Oleh karena itu Ahmadi (2005) keaktifan dapat dikatakan sebagai kegiatan atau kesibukan seseorang atau menggunakan tenaga, pikiran untuk mencapai suatu tujuan tertentu kesemuanya itu untuk mencapai kemampuan optimal.

Wibowo, N (2016) menegaskan bahwa partisipasi aktif peserta didik sangat berpengaruh pada proses perkembangan berpikir, emosi, dan sosial. Beberapa upaya yang dapat dilakukan guru dalam mengembangkan keaktifan belajar peserta didik dalam mata pelajaran dengan meningkatkan minat peserta didik, membangkitkan motivasi peserta didik, serta menggunakan media dalam pembelajaran. Keterlibatan peserta didik dalam belajar, membuat anak secara aktif terlibat dalam proses pembelajaran. Palupi (2016) yang menjelaskan bahwa membentuk kreativitas pada diri peserta didik, dapat dilakukan dengan melatih mereka agar menguasai keterampilanketerampilan pembentuk kreativitas. Ditegaskan pula oleh Harnanik (2014) bahwa kreativitas akan menghasilkan berbagai inovasi dan perkembangan baru dalam suatu kehidupan

\section{Problem Based Learning ( PBL)}

Nurdin dan Adriantoni (2016) menyatakan bahwa PBL merupakan pembelajaran yang digunakan untuk merangsang berpikir tingkat tinggi siswa dalam situasi yang berorientasi pada masalah dunia nyata, termasuk di dalamnya belajar bagaimana belajar. Abidin (2014) menyatakan bahwa PBL mempunyai kelebihan antara lain (1) PBL mampu mengembangkan motivasi belajar siswa. (2) PBL mendorong peserta didik untuk mampu berfikir tingkat tinggi. (3) PBL mendorong siswa mengoptimalkan kemampuan metakognisinya. Rusman (2012) menyatakan bahwa PBL terdiri atas lima fase pembelajaran seperti berikut.

Fase 1: Orientasi siswa kepada masalah; Menjelaskan tujuan pembelajaran, menjelaskan logistik yg dibutuhkan. Memotivasi siswa untuk terlibat aktif dalam pemecahan masalah yang dipilih. Fase 2: Mengorganisasi siswa; Membantu siswa mendefinisikan dan mengorganisasikan tugas belajar yang berhubungan dengan masalah tersebut. Fase 3: Membimbing penyelidikan individu dan kelompok; Mengumpulkan informasi yang sesuai, melaksanakan eksperimen untuk mendapatkan penjelasan dan pemecahan masalah. Fase 4: Mengembangkan dan menyajikan hasil karya; Membantu siswa dalam merencana dan menyiapkan karya yang sesuai seperti laporan, model dan berbagi tugas dengan teman. Fase 5: Menganalisa dan mengevaluasi proses pemecahan masalah; Mengevaluasi hasil belajar tentang materi yang telah dipelajari/meminta kelompok mempresen tasikan hasil kerja

\section{METODE PENELITIAN}

Penelitian ini menggunakan desain Penelitian Tindakan Kelas (PTK) atau Classroom Action Research (CAR). Suharsimi Arikunto, (2012) mengatakan bahwa PTK merupakan bentuk penelitian reflektif yang dilakukan oleh pendidik sendiri terhadap kurikulum dan pengembangan sekolah untuk meningkatkan prestasi belakar, mengembangkan keahlian mengajar, dan sebagainya. Pandangan di atas mengingatkan guru bahwa PTK adalah sebuah upaya untuk mencermati kegiatan belajar anak didik dengan memberikan sebuah tindakan (treatment) yang sengaja dimunculkan Adapun lokasi penelitian dilaksanakan di MTS Muhammadiyah Trucuk Klaten. Waktu penelitian dilaksanakan selama 6 bulan. Waktu penelitian dimulai dari Maret hingga Oktober 2021. Teknik pengumpulan data menggunakan lembar observasi pengukuran hasil proses pembelajaran yang meliputi kemampuan perencanaan, kemampuan pelaksanaan dan 
kemampuan penilaian. Teknik analisis data terdiri dari data kuantitatif.

\section{HASIL DAN PEMBAHASAN \\ Hasil Penelitian}

Data yang diperoleh dari observasi dengan guru kelas diperoleh penjelasan bahwa masih ada beberapa peserta didik yang mendapatkan nilai PPKn yang belum memenuhi standar Kriteria Ketuntasan Minimal (KKM) PPKn yang ditetapkan di MTS Muhammadiyah Trucuk Klaten yaitu 75 . Selain itu peserta didik juga memiliki keaktifan yang rendah dalam mengikuti pembelajaran PPKn. Hal ini karena di masa pandemi Covid-19 ini banyak peserta didik yang tidak belajar karena tidak memiliki handphone Android yang dapat mengakses Google Meet sebagai sarana pembelajaran daring.

Untuk menentukan seberapa rendah kaktifan peserta didik tersebut, peneliti melakukan observasi terhadap proses pembelajaran PPKn di kelas VIIA MTS Muhammadiyah Trucuk
Kabupaten Klaten yang menjadi obyek penelitian. Peneliti menggunakan lembar observasi dengan jumlah item 32 lembar. Observasi dilakukan pada hari Kamis, 24 Juni 2021 pada jam 09.00 - 10.20 WIB dengan Kompetensi Dasar yaitu Perumusan dan Pengesahan UUD NRI 1945.

Penulis adalah tenaga pendidik yang mengampu mata pelajaran Pendidikan Pancasila dan Kewarganegaraan (PPKn) kelas VII di MTS Muhammadiyah Trucuk, Kabupaten Klaten. Penelitian Tindakan Kelas dilakukan di kelas VIIA dengan peserta didik yang berjumlah 30 anak. Pada proses kegiatan belajar mengajar guru masih menggunakan cara konvensional atau ceramah sehingga dirasa kurang efektif, dengan demikian maka perlu adanya perbaikan melalui srategi "Problem Based Learning". Pelaksanaan perbaikan ini dilakukan melalui dua siklus yaitu siklus 1 dan siklus 2, dengan tahapan Perencanaan, Pelaksanaan, Observasi, Refleksi. Adapun prosentase keaktifan peserta didik minimal adalah $70 \%$.

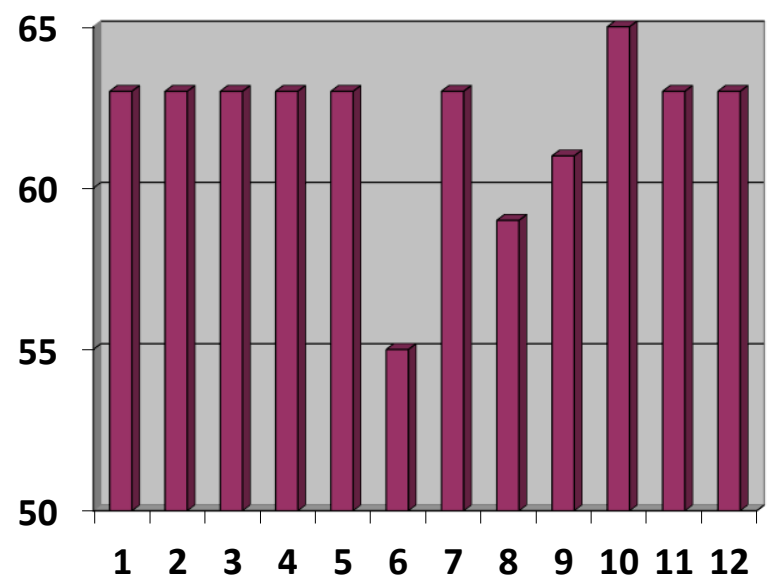

\section{Gambar 1. Hasil Analisis Pra Siklus}

Pada pra siklus dapat menunjukkan tingkat keaktifan peserta didik rata rata $62 \%$ sehingga pembelajaran dengan menggunakan konvensional atau ceramah kurang efektif dan tidak bisa mengaktifkan peserta didik dalam kegiatan pembelajaran.
Pada pra siklus dapat menunjukkan tingkat keaktifan peserta didik rata rata 62 persen, sehingga pembelajaran dengan menggunakan konvensional atau ceramah kurang efektif dan tidak bisa mengaktifkan peserta didik dalam kegiatan pembelajaran. Adapun langkah-Langkah Model Problem Based Learning (PBL) 
1. Orientasi peserta didik terhadap masalah

Model pembelajaran problem based learning diawali dengan tahap orientasi atau pengenalan terhadap masalah.

2. Mengorganisir peserta didik untuk belajar

Pada tahap ini guru dapat melakukan peranannya untuk membantu peserta didik dalam mengorganisir tugas belajar yang terkait dengan permasalahan yang diberikan.

3. Membimbing penyelidikan

Dalam hal ini guru melakukan sebuah bentuk usaha untuk mendorong peserta didik mengumpulkan informasi yang dibutuhkan, melakukan eksperimen serta memecahkan permasalahan yang sudah diberikan.

4. Menyajikan dan mengembangkan hasil karya

Guru memberikan bantuan kepada para peserta didik dalam hal perencanaan dan penyajian karya misalkan laporan dan lain sebagainya. Selain itu guru pun ikut membantu para peserta didik untuk berbagi tugas dalam kegiatan berkelompoknya.
5. Mengevaluasi serta menganalisa proses pemecahan masalah

Keaktifan peserta didik dalam mengikuti proses belajar mengajar dapat dilihat dalam:

a. Memperhatikan dan mendengarkan guru

b. Menjawab pertanyaan guru

c. Mengajukan pertanyaan guru

d. Mencatat penjelasan guru dan hasil diskusi

e. Membaca materi

f. Memberi pendapat ketika diskusi

g. Mendengarkan pendapat teman

h. Memberikan tanggapan

i. Berlatih menyelesaikan soal

j. Berani mempresentasikan hasil

k. Mampu menyelesaikan masalah

1. Minat tinggi pada mata pelajaran

Berdasar pada langkah-langkah Problem Based Learning dan kriteria keaktifan peserta didik maka dapat disusun instrumen pengamatan sebagai berikut.

Tabel 1. Instrumen Pengamatan Keaktifan Peserta Didik

\begin{tabular}{|c|c|c|c|c|c|c|c|c|c|}
\hline \multirow[t]{2}{*}{ No } & \multirow[t]{2}{*}{ Indikator } & \multicolumn{4}{|c|}{ Pernyataan } & \multicolumn{3}{|c|}{ Skor kriteria } & \multirow[b]{2}{*}{1} \\
\hline & & sll & $\operatorname{srg}$ & jrg & tp & 4 & 3 & 2 & \\
\hline 1 & $\begin{array}{l}\text { Apakah peserta didik memperhatikan dan } \\
\text { mendengarkan guru saat diskusi? }\end{array}$ & & & & & & & & \\
\hline 2 & $\begin{array}{l}\text { Apakah peserta didik menjawab pertanyaan guru saat } \\
\text { diskusi? }\end{array}$ & & & & & & & & \\
\hline 3 & $\begin{array}{l}\text { Apakah peserta didik mengajukan pertanyaan saat } \\
\text { diskusi? }\end{array}$ & & & & & & & & \\
\hline 4 & $\begin{array}{l}\text { Apakah peserta didik mencatat penjelasan guru dan } \\
\text { hasil saat diskusi? }\end{array}$ & & & & & & & & \\
\hline 5 & Apakah peserta didik membaca materi saat diskusii & & & & & & & & \\
\hline 6 & $\begin{array}{l}\text { Apakah peserta didik memberi pendapat ketika } \\
\text { diskusi? }\end{array}$ & & & & & & & & \\
\hline 7 & $\begin{array}{l}\text { Apakah peserta didik mendengarkan pendapat teman } \\
\text { saat diskusi? }\end{array}$ & & & & & & & & \\
\hline 8 & $\begin{array}{l}\text { Apakah peserta didik memberikan tanggapan saat } \\
\text { diskusi? }\end{array}$ & & & & & & & & \\
\hline 9 & $\begin{array}{l}\text { Apakah peserta didik berlatih menyelesaikan soal saat } \\
\text { diskusi? }\end{array}$ & & & & & & & & \\
\hline 10 & $\begin{array}{l}\text { Apakah peserta didik berani mempresentasikan hasil } \\
\text { saat diskusi? }\end{array}$ & & & & & & & & \\
\hline
\end{tabular}

Dengan kriteria pengamatan inilah yang menjadi dasar keberhasilan mengaktifkan peserta didik dalam belajar PPKn pada materi Perumusan dan Pengesahan UUD NRI 1945. 


\section{Pembahasan}

Siklus I

Pada siklus 1 tahap yang dilalui yaitu perencaan,tindakan dan refleksi. Adapun pelaksaan dari siklus 1 dapat diamati sebagai berikut:

Tabel 2. Keaktifan peserta didik

\begin{tabular}{lcc}
\hline Aspek Keaktifan Peserta didik & $\begin{array}{c}\text { Jumlah Skor } \\
\text { klasikal }\end{array}$ & $\begin{array}{c}\text { Prosentase keaktifan klasikal } \\
\text { per indikator }\end{array}$ \\
\hline 1. Memperhatikan dan mendengarkan guru & 87 & $68 \%$ \\
2. Menjawab pertanyaan guru & 94 & $73 \%$ \\
3. Mengajukan pertanyaan guru & 87 & $68 \%$ \\
4. Mencatat penjelasan guru dan hasil diskusi & 99 & $77 \%$ \\
5. Membaca materi & 90 & $70 \%$ \\
6. Memberi pendapat ketika diskusi & 79 & $62 \%$ \\
7. Mendengarkan pendapat teman & 98 & $77 \%$ \\
8. Memberikan tanggapan & 80 & $63 \%$ \\
9. Berlatih menyelesaikan soal & 91 & $71 \%$ \\
10. Berani mempresentasikan hasil & 87 & $68 \%$ \\
11. Mampu menyelesaikan masalah & 84 & $66 \%$ \\
12. Minat tinggi pada mata pelajaran & 99 & $77 \%$ \\
$\quad$ Ketercapaian keaktifan Klasikal & & $\mathbf{7 4} \%$ \\
\hline
\end{tabular}

Dari tabel pengamatan keaktifan peserta didik dan distribusi hasil pengamatan dapat dijelaskan sebagai berikut: (a) skor tertinggi untuk keaktifan belajar peserta didik pada indikator nomor empat, tujuh dan nomor 10 dengan jumlah skor klasikal 99 sehingga presentase keaktifan pada indikator ini mencapai $77 \%$. Dengan demikan dapat disimpulkan bahwa prosentase hasil keaktifan indicator sudah diatas standar minimal keaktifan peserta didik . (b) Skor terendah untuk keaktifan belajar peserta didik adalah indikator nomor enam yaitu dengan jumlah skor klasikal 79, sehingga ketercapaian indikator ini mencapai $62 \%$. Dengan demikan dapat disimpulkan bahwa prosentase hasil keaktifan indikator masih dibawah standar minimal keaktifan peserta didik sehingga pada indikator ini masih perlu ditingkatkan. Ratarata keaktifan peserta didik dari indikator 1 sampai dengan 12 mencapai $74 \%$ sehingga dapat disimpulkan bahwa adanya peningkatan terhadap keaktifan peserta didik dalam berdiskusi melalui metode inquiry.

\section{Siklus 2}

Peneliti mengamati proses keaktifan peserta didik melalui model Problem Based Learning. Dari kegiatan tersebut diperoleh deskripsi tentang jalannya proses pembelajaran melalui model Problem Based Learning. Untuk itu peneliti akan menyajikan data tentang aspek keaktifan peserta didik melalui model Problem Based Learning pada tabel dibawah ini. 


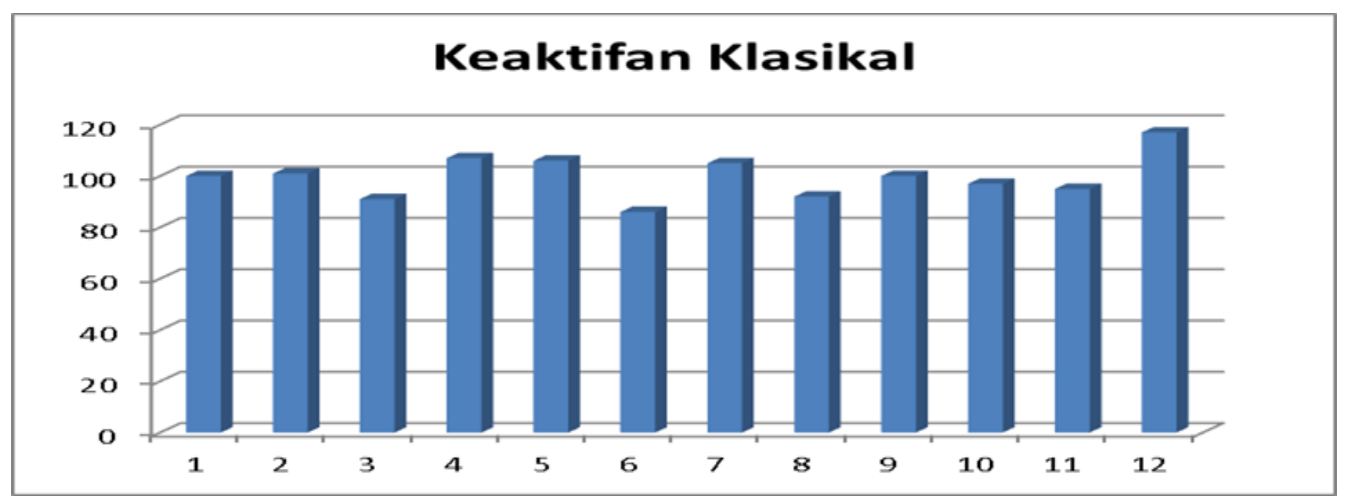

Gambar 2. Keaktifan Peserta didik Siklus 2

Dari tabel pengamatan keaktifan peserta didik dan distribusi hasil pengamatan dapat dijelaskan sebagai berikut: (a) skor tertinggi untuk keaktifan belajar peserta didik pada indikator nomor 12 dengan jumlah skor klasikal 105 sehingga presentase keaktifan pada indikator ini mencapai $82 \%$. Dengan demikan dapat disimpulkan bahwa prosentase hasil keaktifan indikator sudah diatas standar minimal keaktifan siswa . (b) Skor terendah untuk keaktifan belajar siswa adalah indikator nomor 6 yaitu dengan jumlah skor klasikal 80, sehingga ketercapaian indikator ini mencapai $63 \%$. Dengan demikan dapat disimpulkan bahwa prosentase hasil keaktifan indikator masih dibawah standar minimal keaktifan peserta didik, sehingga pada indikator ini masih perlu ditingkatkan. Rata-rata keaktifan peserta didik dari indikator 1 sampai dengan 12 mencapai $73 \%$ sehingga dapat disimpulkan bahwa adanya peningkatan terhadap keaktifan peserta didik dalam berdiskusi melalui strategi pembelajaran PBL.

\section{SIMPULAN DAN REKOMENDASI}

Berdasarkan hasil analis diatas dapat disimpulkan bahwa model pembelajaran Problem based Learning dapat meningkatkan keaktifan siswa pada mata pelajaran PPKn di kelas VIIA MTS Muhammadiyah Trucuk Klaten. Keberhasilan ini diperngaruhi dengan penerapan model pembeajaran problem based learning (PBL) sehingga keaktifan siswa menjadi lebih baik yang berarti siswa memiliki perubahan yang positif dalam mengikuti proses pembelajaran yang diberikan oleh guru maupun dalam melakukan menyelesaikan masalah dalam belajarnya. Dengan kondisi tersebut maka tingkat penerimaan dan keaktifan belajar siswa meningkat. Maksimalnya penerapan model pembelajaran problem based learning (PBL) dalam pelajaran PPKn dibuktikan dengan adanya peningkatan keaktifan siswa dari siklus I ke siklus II. Pada data awal memperoleh nilai rata-rata $62 \%$ siklus I keaktifan belajar peserta didik dengan rata-rata $74 \%$ dan pada siklus II keaktifan peserta didik dengan rata-rata $73 \%$.

\section{DAFTAR PUSTAKA}

Arikunto, S. (2012). Penelitian Tindakan Kelas. Jakarta : Bumi Aksara

Abidin. (2014). Desain Sistem Pembelajaran dalam Konteks Kurikulum. Bandung: PT Gramedia.

Ahmadi, A., dan Pasetya, J. T. (2005) Strategi Belajar Mengajar. Bandung: Pustaka Setia.

Asmani, J. M. (2012). Buku Panduan Internalisasi Pendidikan Karakter di Sekolah. Yogyakarta : Diva Press.

Rusman. (2012). Model-model Pembelajaran: Mengembangkan Profesionalisme Guru. Jakarta: Raja Grafindo Persada.

Hendriana, H., \& Soemarmo, U. (2014). Penilaian Pembelajaran Matematika. Bandung: PT Refika Aditama 
Jurnal PAJAR (Pendidikan dan Pengajaran)

Volume 5 Nomor 6 November | ISSN Cetak : 2580 - 8435| |ISSN Online : 2614 - 1337

DOI : http://dx.doi.org/10.33578/pjr.v5i6.8569

Palupi, D., T. (2016). Cara Mudah Memahami Kurikulum. Surabaya: Jaring Pena.

Nurdin, S. \& Adriantoni. (2016). Kurikulum Dan Pembelajaran. Jakarta: PT Raja Grafindo Persada

Wibowo, N. (2016). Upaya Peningkatan Keaktifan Peserta didik melalui Pembelajaran Berdasarkan Gaya Belajar di SMK Negeri 1 Saptosari. Jurnal Electronic, Informatics and Vocational Education (ELINVO), 1 (2), 128-139.

Widyatiningtyas, Reviandari, dkk. ( 2015). The Impact of Problem-Based Learning Approach to Senior High School Students' Mathematics Critical Thinking Ability. IndoMS-JME, 6(2), 30-38.

Zaeni, H. (2011). Strategi Pembelajaran Aktif. Yogyakarta: CTSD. 